2. Орнацкая, Т.А. Общая теория права: учебно-методическое пособие / Т.А. Орнацкая. - Хабаровск: ХПИ ФСБ России, 2016. - 115 с.

3. Орнацкая, Т.А., Ципкин, Ю.Н. Борьба Советской России и Дальневосточной республики за ликвидацию интервенции на Северном Сахалине в 1920-1925 гг. / Т.А. Орнацкая, Ю.Н. Ципкин // Проблемы Дальнего Востока. - 2008. - № 2. - С. 138-152.

4. Орнацкая, Т.А., Цуканов, С.С. Дальневосточный революционный комитет: цели, задачи, структура / Т.А. Орнацкая, С.С. Цуканов // История государства и права. - 2010. - № 3. - С. 31-35.

5. Ц Цуканов, С.С. Вклад Дальневосточного революционного комитета в развитие региона (1922-1926 гг.) / С.С. Цуканов - Хабаровск, 2017.

6. Цуканов, С.С. Военная реформа 1924-1925 гг. глазами японского разведчика / С.С. Цуканов // Военно-исторический журнал. - 2011. - № 4. - С. 29-37.

7. Цуканов, С.С. Реорганизация органов государственной безопасности СССР в первые месяцы Великой Отечественной войны / С.С. Цуканов // Общество : философия, история, культура. - 2018. - № 1. - С. 99-102.

8. Шабельникова, Н.А. Милиция в системе охраныправопорядка на Дальнем Востоке России в 1920е гг. / Н.А. Шабельникова. - Владивосток: Изд-во ДВФУ, 2019. - 126 с.

9. Шабельникова, Н.А., Шепотько, Л.В., Усов, А.В. История государства и права России / Н.А. Шабельникова, Л.В. Шепотько, А.В. Усов. - М.: Проспект, 2017. - 240 с.

\title{
Чимаров Н.С. \\ Конституционно-правовая защита избирательных прав граждан в условиях реализации технологии регистрации по биометрическим показателям: на примере зарубежного опыта
}

Северо-Западный институт управления Российской академии народного хозяйства и государственной службы при Президенте РФ

doi: 10.18411/lj-04-2021-260

(Россия, Санкт-Петербург)

\section{Аннотация}

В статье представлен анализ национальной модели новой технологии голосования посредством задействования биометрических показателей избирателей в Кыргызской Республике. Выявляя отдельные стороны нормативно-правового закрепления данной технологии, автор акцентирует внимание на ее потенциале, в части соответствия духу национального конституционализма и укреплению доверия населения к электоральным процедурам инновационного характера.

Ключевые слова: избирательные права граждан, конституционализм, новые технологии голосования, избирательный процесс, выборы, биометрические данные.

\section{Abstract}

The article presents an analysis of the national model of a new voting technology through the use of biometric indicators of voters in the Kyrgyz Republic. Identifying certain aspects of the normative and legal consolidation of this technology, the author focuses on its potential, in terms of compliance with the spirit of national constitutionalism and strengthening public confidence in electoral procedures of an innovative nature.

Keywords: electoral rights of citizens, constitutionalism, new voting technologies, electoral process, elections, biometric data.

Конституционные гарантии основных прав человека и примат верховенства права выступают основой развития конституционализма в странах с развивающейся демократией. В этой связи, представляется важным исследование демократических преобразований в избирательных системах отдельных стран с отмеченным выше уровнем развития демократии. Универсальный характер правовых избирательных стандартов новых технологий голосования способствует динамичному развитию различных избирательных систем. С учетом изложенного, мы считает необходимым наиболее подробно исследовать опыт реализации некоторых электоральных процедур в 
соответствии с правовыми избирательными стандартами новых технологий голосования на примере избирательного процесса в Кыргызской Республике (далее КР). В указанном государстве правовая модель технического переоснащения избирательного процесса впервые была закреплена в Кодексе от 29 мая 1999 г. № 39 «О выборах в Кыргызской Республике». В соответствии с правовыми нормами пункта 4 ст. 24 и ст. 49 данного Кодекса, инновационный аспект избирательных правоотношений, связанных с подготовкой и проведением выборов Президента, депутатов Парламента (Жагорку Кенеша) и местных кенешей был обусловлен применением автоматизированной информационной системы (АИС) «Шайлоо» (от кырг. «Выборы») [3]. Первое применение АИС «Шайлоо» было осуществлено 20 февраля 2000 г. во время первого тура выборов в обе палаты Жогорку Кенеша (от кырг. «Верховный Совет»). С учетом современных достижений IT-технологий, технические возможности АИС «Шайлоо» предусматривали решение задач учета избирательского корпуса, регистрации кандидатов, подготовки данных для проведения процедуры голосования, ускорения процесса обработки итогов голосования и их наглядного отображения в виде таблиц и диаграмм.

Разработанная российскими специалистами модель применения АИС «Шайлоо» позволила КР получить среди государств Центральной Азии первый опыт публичного представления хода и итогов голосования в сети Интернет на специальном созданном сервере ЦИК Республики.

В 2014 г. в Кыргызстане была завершена работа по подготовке программного документа «Автоматизации процесса идентификации избирателей в ходе избирательного цикла 2015-2017 гг.» [6]. Отмеченный документ разработан по Программе OOH KESP-II («Kyrgyz Election Support Project»), с участием Агентства Японии по международному сотрудничеству («JICA») [9]. Реализация в рамках проекта KESP-II технологии электронной системы идентификации избирателей («ЭСИИ») предполагала строгое следование правовому избирательному стандарту прозрачности выборов. Идеология электронной идентификации избирателей получила закрепление в пункте 2 (подпункт 2 - «составление актуализированного списка избирателей») ст. 2 Закона КР от 14 июля 2014 г. № 136, регламентирующего правомерность создания базы данных граждан КР на основе их биометрических данных (цифрового графического изображения лица, графического строения папиллярных узоров пальцев обеих рук, собственноручной подписи) и персональных данных, включая PIN гражданина [2].

Первое применение в национальном масштабе кыргызской модели биометрической регистрации произошло 20 октября 2014 г. При этом, для проживающих за рубежом кыргызстанских граждан регистрация параметров их биометрии проводилась на опорных пунктах при посольствах Республики. К примеру, пункт сбора биометрических данных при посольстве в Берлине позволил пройти регистрацию избирателям, проживающим на территории не только Германии, но и ряда других европейских стран. Вместе с тем, новая технология учета биометрических данных избирателей выявила свои недостатки. По результатам проведенного гражданскими активистами исследования среди электората Баткенской области КР было установлено, что менее чем за месяц до официальной даты проведения выборов 4 октября 2015 г. около 76\% граждан области, потенциально входящих в состав избирательского корпуса, не обнаружили себя в списках национального биометрического Регистра. В целом же по Республике число таких граждан по данным партии «Бир бол» составило от 15 до 20\% [7]. Представляется, что фактор невключения избирателей в биометрический Регистр объясним не только с точки зрения возникших проблем в механизме регистрации граждан, но и по причине нахождения отдельных из них на позициях абсентеизма, и, как следствие, уклонения ими от прохождения процедуры биометрической регистрации. Несмотря на выявленные недостатки, следует признать, что апробированная в РК национальная модель парламентских выборов 2015 
г. продемонстрировала инновационный характер, суть которого заключается в использовании биометрических данных избирателей и автоматического подсчета голосов избирателей посредством автоматически считывающих урн голосования (электронных урн).

В соответствии с поправками в Закон «О выборах Президента Кыргызской Республики и депутатов Жогорку Кенеша Кыргызской Республики» (в редакции конституционного Закона Кыргызской Республики № 88 от 23 апреля 2015 г.) из перечня документов, удостоверяющих личность избирателя исключены удостоверение офицера (прапорщика), военный билет военнослужащего (проходящего службу по призыву), пенсионное и водительское удостоверение. Основными документами, идентифицирующими избирателя, являются паспорт - «ID-card» и общегражданский паспорт. Кроме того, исключена правовая норма об обязательной маркировке избирателей специальным составом. Важно заметить, что идентификация избирателя по его биометрическим и персональным данным осуществляется в помещении для голосования членами участковых избирательных комиссий совместно с операторами, а для идентификации избирателя по его биометрическим и персональным данным согласие избирателя не требуется. После прохождения избирателем процедуры идентификации и получения соответствующего чека, член избирательной комиссии выдает избирателю бюллетень для голосования (в обмен на чек).

Биометрическая регистрация граждан Кыргызстана создается с целью формирования актуализированной базы граждан Кыргызской Республики и в интересах составления актуализированного списка избирателей. При этом сбору, обработке, хранению и использованию в обязательном порядке подлежат следующие биометрические данные: 1) цифровое графическое изображение лица; 2) графическое строение папиллярных узоров пальцев обеих рук; 3) собственноручная подпись. По убеждению председателя Государственной регистрационной службы Кыргызстана А. Шаиковой, полная биометрическая регистрация граждан страны позволит реализовать принцип «один человек - один паспорт - один ПИН», а в избирательном процессе принцип «один человек - один паспорт - один ПИН - один голос» [1].

В интересах технологического обеспечения транспарентности парламентских выборов, ЦИК Кыргызстана организовала ярмарку современного биометрического и электорального оборудования и программных систем. Проанализировав электоральные возможности соответствующей продукции различных компаний из Европы, США, Израиля, России, Японии и Кореи, специально созданная рабочая группа из представителей госсектора и НПО остановила свой выбор на биометрике Японии. В соответствии с заключенным грантовым соглашением японская сторона в интересах Государственной регистрационной системы и ЦИК Кыргызстана поставила в Республику на сумму 6 млн. долларов комплект «из трех тысяч ноутбуков, трех тысяч сканеров отпечатков пальцев, трех тысяч термопринтеров, 2,5 тысячи настенных мониторов и др.» [5]. Каждый избирательный участок в Кыргызской Республике к моменту парламентских выборов (2015 г.) был оборудован камерами видеонаблюдения, ноутбуками, техникой для считывания ID-карт, отпечатков пальцев и автоматически считывающими урнами (основными и запасными). Правовая основа применения в избирательном процессе автоматически считывающих голоса избирателей урн закреплена в Законе № 68 от 2 июля 2011 г. (ст. 31, 34) [4]. Сам алгоритм Кыргызской модели инновационного голосования выглядит следующим образом: а) определение на избирательном участке биометрических данных избирателя с одновременным отражением на мониторе его паспортных данных; б) получение избирателем бюллетеня с последующим его пропуском через сканирующее устройство автоматически считывающей урны; в) выдача автоматической урной после окончания выборов готового протокола о количестве поданных бюллетеней (с последующей его подписью членами избирательной комиссии и ознакомлением наблюдателей). Таким образом, национальная модель КР в части реализации избирательных прав граждан 
продемонстрировала стремление государства к обеспечению транспарентности избирательного процесса и повышение уровня электоральной активности граждан по реализации своих избирательных прав. По нашему мнению, отмеченный подход к организации выборов корреспондирует духу конституционализма, выступающего в качестве общего политико-правового символа, согласно которому в обществе действует гарантия предотвращения произвола по отношению к соблюдению конституционно зафиксированных прав и свобод [8, с.29].

Резюмируя изложенное, следует заметить, что: во-первыx, модернизация современного избирательного процесса выступает неизменным фактором упрочнения демократизма национальной избирательной системы и ее соответствия вектору развития информационного общества; во-вторых, рассмотренная технология регистрации избирателей по их биометрическим показателям несомненно способствует повышению уровня доверия граждан к проводимым выборам и содействует повышению легитимности формируемых по итогам проведенных выборов представительных органов власти.

$$
* * *
$$

1. Ащеулов Д. Выборы - 2015: внедряем инновации. - URL: http://www.slovo.kg?p=33282 (дата обращения: 03.03.2021)

2. Закон КР от 14 июля 2014 г. № 136 «О биометрической регистрации граждан Кыргызской Республики» от 14 июля 2014 года // Эркин Тоо, 18 июля 2014 г. - № 56.

3. Кодекс Кыргызской Республики от 29 мая 1999 г. № 39 «О выборах в Кыргызской Республике» // Ведомости Жогорку Кенеша Кыргызской Республики. - 1999 г. - № 9. - Ст. 436.

4. Конституционный Закон Кыргызской Республики от 2 июня 2011 г. № 68 «О выборах Президента Кыргызской Республики и депутатов Жогорку Кенеша Кыргызской Республики». - URL: http://www.grs.gov.kg/ru (дата обращения: 05.03.2021)

5. Подольская Д. Кыргызстану поможет с биометрикой Япония. - URL: http://www.24.kg/vybory (дата обращения: 04.03.2021)

6. Свободные, честные и прозрачные выборы - вклад в устойчивое развитие Кыргызстана. - URL: http://www.kg.undp.org/content/kyrgyzstan/ru/home/presscenter/articles/2015/08/12/-0.html （дата обращения: 09.03.2021)

7. Токсонбаев А. $76 \%$ избирателей Баткенской области не находят себя в избирательном списке. URL: http://www.gezitter.org/vybory/43704_76_izbirateley_batkenskoy_oblasti_ne_nahodyat_sebya_ v_izbiratelnom_spiske (дата обращения: 27.02.2021)

8. Чимаров Н.C. Сравнительный анализ проблемы определения конституционализма в отечественной и зарубежной юриспруденции // Вестник Санкт-Петербургской юридической академии. - 2020. - № 4 (49). - С. 26-30.

9. Kyrgyz Election Support Project (KESP II). UNDP. - URL: https://info.undp.org/docs/pdc/Documents/KGZ/Review\%20ProDoc_Grant_Kyrgyz_Election_2

9Jan2015_JICA_20.03.15.docx (дата обращения: 05.03.2021)

\section{Шамне А.Н. \\ Влияние причин миграции на миграционно-правовую политику государства}

Волгоградский государственньй университет (Россия, Волгоград)

doi: 10.18411/lj-04-2021-261

\section{Аннотация}

В статье на примере Германии рассматривается феномен миграции с точки зрения типологии, выделяются причины миграции в качестве значимого дифференцирующего признака. В рамках причин разграничиваются факторы выталкивания и притяжения. Характеризуется современная миграционная ситуация Германии. Делается вывод о необходимости законодательной регламентации процесса интеграции мигрантов.

Ключевые слова: миграция, виды миграции, причины миграции, факторы выталкивания и притяжения, миграционная политика 